\title{
Family Involvement, agency cost of debt financing, and small firm performance: research agenda
}

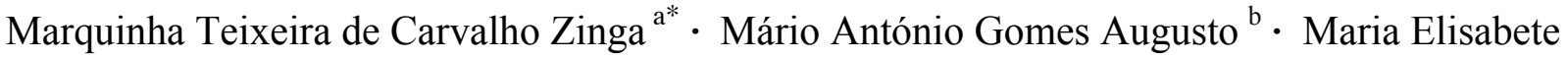 \\ Gomes Ramos ${ }^{c}$ \\ ${ }^{a, b, c}$ School of Economics, University of Coimbra, Coimbra, Portugal
}

\section{A T O S A R T ÍC U L O}

Historial:

Recibido 09-02-2013

Aceptado 10-05-2013

Palabras clave:

Costos de agencia de la

deuda

Relaciones familiares,

Pequeñas empresas

Performance

Códigos JEL:

L25, L26, M10

\begin{abstract}
R E S U M EN
El objetivo de este estudio es examinar las pequeñas empresas familiares desde el punto de vista de los efectos de las relaciones familiares en la propiedad y en la gestión de costos de agencia causados por la financiación con deuda, y en su performance. Para lograr este objetivo hemos revisado la literatura sobre empresas familiares desde la perspectiva de la Teoría de Agencia, proponiendo un modelo de investigación que pone de relieve los vínculos entre las variables. Este trabajo añade a la literatura tres contribuciones: ayuda a explicar cómo los comportamientos disfuncionales pueden perpetuar las limitaciones de la pequeña empresa o incluso su fracaso, hace la propuesta de la comprensión de los mecanismos de gobierno corporativo en pequeñas empresas familiares y se profundiza la discusión de la investigación previa a través de un conjunto de proposiciones. Creemos que una comparación sistemática de los diferentes contextos proporciona nuevos conocimientos sobre la gobernanza de las pequeñas empresas familiares. En la última sección presentamos las implicaciones de este estudio y líneas para futuras investigaciones.
\end{abstract}

A R T I C LE I N F O

Article history:

Received 09-02-2013

Accepted 10-05-2013

Keywords:

Agency debt of financing

Family involvement

Small firms

Performance.

JEL codes:

L25, L26, M10
A B S T R A C T

The aim of this study is to examine the effects of family involvement in ownership and family involvement in management on agency costs of debt financing, as well on the performance of small family business. To achieve this objective, we reviewed the literature on family business, and drawing from agency theory we proposed a research model that highlights the links between the variables. Our paper makes contributions to the literature in three ways. Firstly, it helps to explain how dysfunctional behaviours may perpetuate small business constraints or even failure. Secondly, it advances the understanding of corporate governance mechanisms in small family business. And finally, it deepens the discussion of prior research, by advancing a set of propositions. We believe that a systematic comparison of different contexts provides new insights into small family business governance. Implications and directions for future research appear in the last section.

\footnotetext{
*Autor de contacto.

Correoselectrónicos: marquinha.carvalho@student.fe.uc.pt,maugusto@fe.uc.pt,mgramos@fe.uc.pt
} 


\section{Introducción}

Small firms are the backbone of the world economy and the role they play in economic growth, employment, and poverty alleviation is unquestionable. For instance, Wymenga, Spanikova, Barker, Konings, and Canton (2012) report that small and medium enterprises account for $99.8 \%$ of non-financial enterprises, providing $67.4 \%$ of jobs and sharing $58.1 \%$ of the gross value added in the European Union. Despite this fact, small firms often face difficulties in obtaining equity and debt financing, which constrains their development and success (Storey, 1994), and many of these shortcomings are caused by potential conflicts of interest and asymmetric information between borrowers and lenders. In this regard, it is important to note that contractual solutions are available to large firms (Smith \& Warner, 1979), but often not to smaller ventures (Peterson \& Rajan, 1994). Debt financing of small firms is more complicated by their liability of newness and opacity in terms of available information (Berger \& Udell, 2002), and since what functions for large firms may not work for small firms, there is an opportunity for conducting additional research on small family firms' debt financing.

In undertaking such research, the salient features of small firms, which are the family involvement in ownership, in management, and the employment of several family members in the firm (Chua, Chrisman, \& Sharma, 1999), must be considered because they embody behaviours and dynamics that are unique to, and introduced by, family members (Kidwell, Eddleston, Cater, \& Kellermanns, 2012), and that may cause conflicts. Additionally, they can distinguish family from non-family firms, and simultaneously explain variations of behaviour within family firms (Chrisman, Chua, \& Sharma, 2005). In this regard, family business becomes a unique area of research that has experienced an exponential growth, and many researchers have attempted to define such firms (Chua et al., 1999), while others have attempted to examine and explain not only the extent to which the family involvement affects firm performance, but also whether family firms differ from non-family firms (e.g. Chrisman, Chua, \& Litz, 2004; Sciascia \& Mazzola, 2008; Chua, Chrisman, \& Bergiel, 2009). These attempts yield inconsistent results (e.g. Anderson \& Reeb, 2003; Sciascia \& Mazzola, 2008) and, since as stated previously, the majority of firms worldwide are small, unlisted ventures, research focuses almost exclusively on large publicly-traded firms (e.g. Anderson, Mansi, \& Reeb, 2003; Chu, 2009). Just to exemplify, researchers conclude that family and non-family firms are clearly different, for instance, in terms of goals (Chrisman et al., 2005), equity (Romano, Tanewsky, \& Smyrnios, 2000), corporate governance (Randøy \& Goel, 2003), international structures and strategies (Zahra, 2003), and sources of debt financing (Voordeckers \& Steijvers, 2008; Chua, Chrisman, Kellermanns, \& Wu, 2011). On the other hand, others conclude that the relationship between family involvement and firm performance is too complex and is very likely to be moderated or mediated by factors that are not included in the analyses (Chrisman, Chua, Pearson, \& Barnett, 2012). For example, Chrisman et al. (2004) examined small privately-owned US family and non-family firms and found an insignificant effect of family involvement on sales growth. Herrero (2011) found positive effects of family involvement on the efficiency of fishing business, while Cucculelli and Micucci (2008) report results revealing that the maintenance of management within the family has a negative impact on firm performance.

Similar results were reported by Sciascia and Mazzola (2008), concluding that the relationship between family involvement in management and performance is negative and non-linear, and that family involvement in ownership does not significantly affect firm performance. Steijvers, Voordeckers and Sigrid (2007), using a sample frame of 2,865 small family firms, found that firms led by a family manager holding a large ownership share ( $\geq 80 \%)$ or being accompanied by few other owners, have significantly lower profitability. These results suggest that there are some family behaviours or activities that destroy firm value. In this line, Cater et al. (2006) report that $30 \%$ 
of small businesses pass to the second generation, $12 \%$ pass to the third generations, and $4 \%$ to the fourth generations.

Even with this steady increase of studies on family firms, it is notable that the link between family involvement and agency cost of debt financing in small family firms remains relatively unexplored (e.g. Steijvers \& Voordeckers, 2009; Chua, Chrisman, Kellermanns, Wu, 2011). Given the scant empirical studies on this stream of research, and being consistent with the previous research on family firms (Schulze, Lubatkin, Dino, \& Buchholtz, 2001), this study aims to examine the effects of family involvement in ownership and in management on agency costs of debt financing, as well on performance. To attain this objective, we review the literature on small family firms, and we overarch our arguments on agency theory by highlighting the conflicts rooted in the relationship between borrowers and lenders (Voordeckers \& Steijvers, 2006).

The paper is structured as follows. First, the literature on family business is reviewed. This is followed by a section on the research model in which the propositions are discussed and presented. The last section is devoted to the discussion, and directions for future research.

\section{Literature Review}

Agency theory highlights the conflict rooted in the separation of ownership from control, that is, the principal-agent problem (Ross, 1973). According to Jensen and Meckling (1976), shareholding causes de facto delegation of some decision-making authority from the firm's owners to its agents. This delegation of authority exposes agents at every level of the firm to risks for which they are not fully compensated. This uncompensated risk gives agents the incentive to free-ride or shirk in an effort to obtain additional compensation (Schulze, Lubatkin, \& Dino, 2002), creating information asymmetries (Stiglitz \& Weiss, 1981) that make it possible for agents to engage in self-serving behaviour that, if unmonitored, would threaten firm survival (Meyer \& Zucker, 1989), thereby damaging the interests of principals and other stakeholders (Schulze, Lubatkin, \& Dino, 2003a).

It is difficult for the principal to monitor the actions of the agents in a situation where there is information asymmetry. In such circumstances agency costs arise, representing the cost of all activities and operating systems designed to align the interests and/or actions of managers (agents) with the interests of owners (principals). From this point, researchers have realized that both concentrated ownership and owner-management mitigate these conflicts and costs (Jensen \& Meckling, 1976; Fama and Jensen, 1983; Fleming, 2005). Fama and Jensen (1983), for example, argue that the family management model is especially efficient, because owner-management allows alignment of interests, and substitutes the costly control mechanisms that non-owner-manager firms use to mitigate agency costs. In this sense, family businesses embody the beliefs, norms of reciprocity, aspirations, common histories, and self-concepts that are likely to create collectivistic behaviour (Davis, Schoorman, \& Donaldson, 1997), which, in turn, tempers selfserving behaviour, and the conflict it can cause, by fostering loyalty and commitment to the family and firm (Corbetta \& Salvato, 2004). As such, theory suggests that there should be little need to offer these agents performance incentives (Fama \& Jensen, 1983, 1985) or implement formal monitoring mechanisms (Chrisman, Chua, Kellermanns, \& Chang, 2007), which might even be counter-productive (Jensen \& Meckling, 1976). In this line, Chrisman et al. (2007) argue that family firms are an exclusive field of interest because conflicts between owners and managers are minimized as a result of altruism and family involvement in both ownership and management. Accordingly, previous empirical evidence reveals that family involvement generally has positive effects on the performance of listed firms (Anderson et al., 2003; Vilalonga \& Amitt, 2006, Maury, 2006; Chu, 2009), but the results for non-listed firms are mixed. For example, Chrisman et al. (2004) examined 1,141 small privately-held US family and non-family firms and found that agency costs are less severe in family businesses, in 
spite of the insignificant effect of family involvement on sales growth. Likewise, Herrero (2011) found positive effects of family involvement on the efficiency of fishing business, while Cucculelli and Micucci (2008) report results revealing that the maintenance of management within the family has a negative impact on firm performance. Similar results were reported by Sciascia and Mazzola (2008), concluding that the relationship between family involvement in management and performance is negative and non-linear, and that family involvement in ownership does not significantly influence firm performance. This suggests, however, that family involvement may increase agency costs. In this regard, Minichilli, Corbetta, and MacMillan (2010) report a positive U-shaped effect attributed to schisms in family, and Mazzola, Sciascia and Kellermans (2012), based on a sample of 294 small privately-held family firms, report an inverted U-shaped relationship between family involvement and firm performance. These results suggest that concentrated ownership and owner-management can mitigate the traditional agency problems, but in contrast, create specific agency problems (e.g. Schulze et al., 2002; Schulze et al., 2003a). That is, family involvement has advantages and disadvantages.

This stream of research rests on Lansberg's (1983) assumptions that institutional overlap nature of family business may cause a managerial dilemma, such that social relations in the family are structured to satisfy family members' various development needs (Lansberg, 1983). On the other hand, a business's fundamental function is the generation of goods and services at competitive prices in order to maximize firm profits. Hence, social relations in firms are, or should be, guided by principles and norms that facilitate the productive process. However, the linking of the parents'/owners' welfare with that of their children compels owner-managers to place noneconomic family goals (e.g. family harmony, social status) before the economic goals of their firms (Chrisman et al., 2012). In other words, family owner-managers may have aspirations and goals that conflict with those of the business; for example, employing family members independently of their skill, may be more important to the leaders of family firms than the objective of maximizing profits (Kidwell et al., 2012), which ultimately may cause conflicts (Chrisman, Chua, \& Steier, 2002) because the family is not a homogeneous group of people with the same set of interests, goals and motivations. Thus, we argue that if the heterogeneous interests and their potential conflicts among family members are not well managed they may threaten firm profitability, destroy firm and family assets (Kidwell et al., 2012), and negatively affect the bargaining power with principals' suppliers, namely financial institutions (Voordeckers \& Steijvers, 2006). There is evidence of a positive association between external finance and business performance (Keasy \& McGuiness, 1990). This is because the provision of debt financing by a bank to a small business is essentially an agency problem in which the bank (principal) is using the firm (agent) to generate a return on money advance. Thus, the firm incurs an implicit (personal and business collateral) and explicit cost (interest tax, credit rationing).

\section{Research Model and Propositions}

\subsection{Family Involvement (in ownership and management) and Agency Cost of Debt Financing}

One of the outstanding characteristics of small firms is the involvement of family in the business through ownership and management. Therefore, it is argued that an increase in family involvement influences the potential that a firm will adopt distinct goals (Chrisman et al., 2012), behaviours, and outcomes (Tagiuri \& Davis, 1992, 1996; Chrisman et al., 2005; Dyer, 2006). This is because it provides sufficient latitude for decision-making, and it is expected that as the number of family members increases, the more the interests should be aligned (Fama \& Jensen, 1983). Such alignment will thus lower the agency costs derived by the asymmetric information (Jensen \& Fama, 1976). In this line, researchers agree on the fact that family involvement often requires long term affinities 
within the firm, which brings benefits for the owners with longer investment horizons (Faccio, 2010). These are: less managerial myopia (Stein, 1989), efficient investments (James, 1999), and better control of managers' activities (Fama \& Jensen, 1983). In addition, family firms with large undiversified assets are usually, as stated above, to be long-term investors with substantial wealth at risk, and willing to pass the firm to their heirs in order to maintain the control. Furthermore, the long-term perspective can be constructive in building trust between firms and financial institutions (Teijevers \& Vooddeckers, 2009), since servicing the firm's debt is necessary for survival, because it aligns the interests of the lender and borrower (Chua et al., 2011). As such, family firms incur a lower probability of pledging collateral or personal commitments (Steijvers, Voordeckers, W., \& Vanhoof, 2010), and lenders are less exposed to risk, a circumstance which should make them more willing to lend to family firms (Smith \& Warner, 1979). This is consistent with the results reported by Anderson et al. (2003) that founding family ownership impacts upon the agency cost of debt, suggesting thus, that founding family firms have an incentive structure that results in few agency conflicts between equity and debt claimants. Put differently, family involvement in ownership may reduce the agency costs of debt financing because of the lower probability of managerial opportunism, higher risk aversion, and longterm orientation. However, the literature concerned with both agency theory and family firms is inconclusive about whether family involvement alone, affects the creditworthiness of a firm because such involvement may increase or reduce the agency cost of debt financing. Based on the above arguments, we propose that:

P1: Family involvement in ownership will have an U-shaped relationship with the agency cost of debt financing.

P2: Family involvement in management will have an U-shaped relationship with the agency cost of debt financing.

\subsection{Family Involvement (in ownership and management) and Small Family Firm Performance}

The effects of family involvement in ownership and management on firm performance have been reported by many scholars. For example, McConaughy, Walker, Henderson, and Mishra (1998) present evidence that firm value is higher when ownership is concentrated in the hands of the founding family than when the ownership is concentrated, but not in the hands of the founding family. In the same vein, Anderson and Reeb (2003), by using a sample of firms from the S \& P 500, conclude that accounting profitability measures are higher for owner-managed firms but market value creation is higher for those with founding family ownership and either a founding CEO or nonfamily CEO.

As they observed later, the superiority in performance is tempered by the need to balance the interests of the family, as the dominant shareholder, against those of other shareholders (Anderson et al., 2003; Anderson \& Reeb, 2004). Chrisman et al. (2002) also observed that family involvement in ownership enhances the first year sales of new ventures, and Zahra (2003) reports higher sales in international operations of family firms, suggesting thus, that family involvement reduces the agency costs. In their study, Chrisman et al. (2004) also report that short-term sales growth for small family and non-family firms are statistically equal, and that strategic planning, as a mechanism for controlling agency costs, has a stronger positive effect on the performance of non-family firms. These results suggest that even if the overall agency costs of family businesses are not negative, they are lower than those in nonfamily firms, which is consistent with Fama and Jensen (1983) who assumed that when ownership and management reside within a family, agency costs would be lower, if not absent. Yet, recent studies have also concluded that small family firms could be very vulnerable to agency problems (Schulze et al., 2001, 2002; 2003a; Chrisman et al., 2005), because a family is not necessarily a homogeneous group of people with congruent interests (Sharma, 
Chrisman \& Chua, 1997), and is often plagued by substantial conflicts. That is, families are emotional entities and their relationships are characterized by complexities arising from family members' self-interest, perspective, and identity conflicts with moral and filial duties towards other family members (Schulze et al., 2003a). If these conflicts are not managed, they can result in negative emotions like resentment and animosity (Schulze et al. 2003a; Chrisman et al., 2005), which are extrapolated to the business arena by family involvement. Those conflicts may come at particularly high costs in family firms because family members are confined within the firm, thereby making conflicts more persistent and interests more difficult to align (Schulze, Lubatkin, \& Dino, 2003b; Kellermanns \& Eddlesson, 2004). For example, DeAngelo and DeAngelo (2000) found that relationships within the family firm are capable of reducing firm value through excessive compensation, related partytransactions or special dividends.

In the same vein, it is argued that nepotism often characterizes the selection of managers by family owners, with the subsequent negative impact on company management and results (Lansberg, 1983), and that particularism makes it difficult for owning families to effectively evaluate family members (Dyer, 2006), and dismiss them in the case of unsatisfactory performance (Gomez-Meja, Nunez-Nickel, \& Gutierrez, 2001). In other words, the war of love and hatred typical of kinship ties, blinds the family members, destroys family assets, and removes the opportunity to join synergy and turn the firms into more competitive and profitable entities. As a result, these family firms will shortly become failed firms that perform poorly on both family and business dimensions (Sharma, 2004). In summary, while family involvement in ownership may reduce and increase the agency costs of debt financing, this led us to argue, as observed by Sciascia and Mazzola (2008), that it may have both positive and negative effects on small family performance. Thus, we propose that:

P3: Family involvement in ownership will have an inverted U-shaped relationship with small family firm performance.

P4: Family involvement in management will

\section{Figure 1}

Research model.

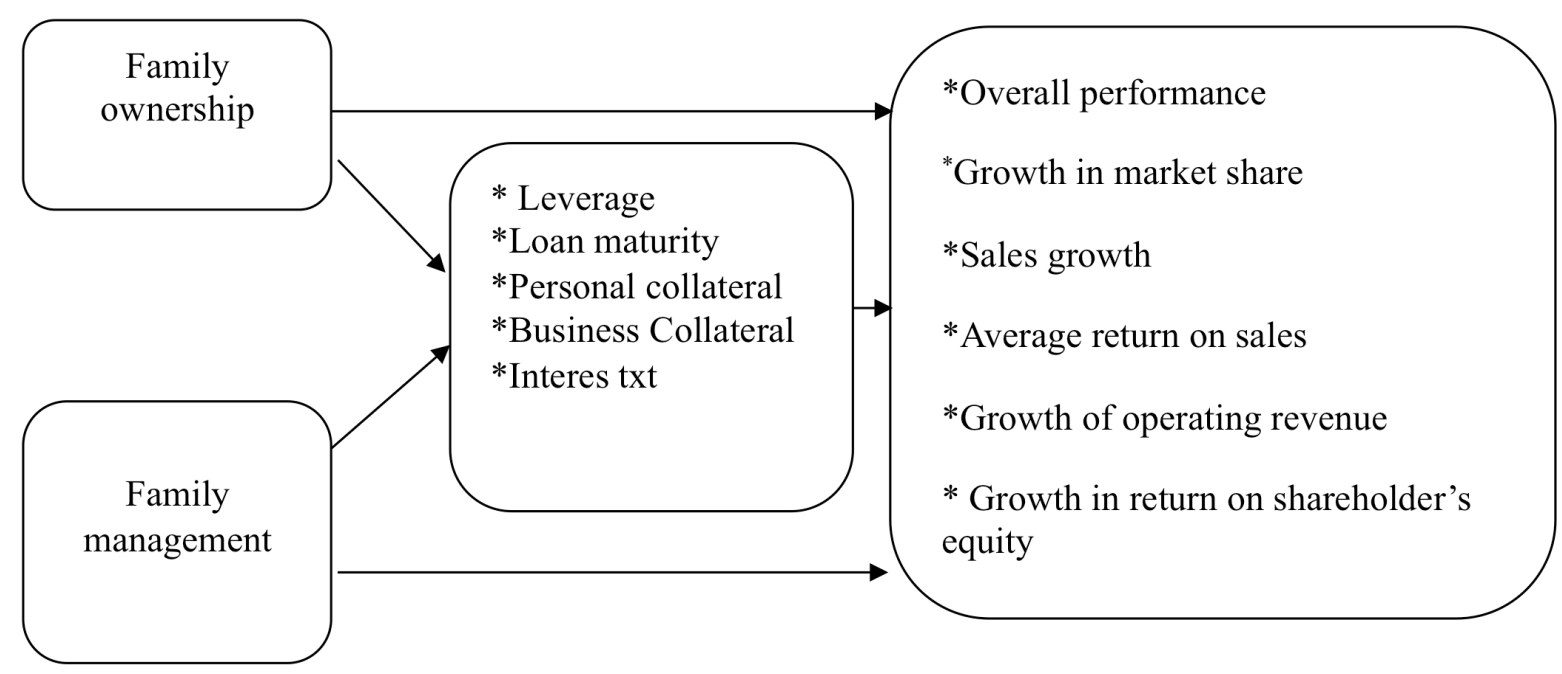


have an inverted U-shaped relationship with small family firm performance.

\section{Discussion and Directions for Future}

\section{Research}

In this article we tried to understand how family involvement influences firm performance, by mitigating the agency costs of debt financing. In so doing, we reviewed the literature on the family business and proposed a research model that highlights the directional paths between the constructs, in an integrated fashion. As observed by researchers (e.g. Schulze et al., 2001, Chrisman et al., 2005; Lubatkin et al., 2005), the two constructs (family involvement in ownership and in management) have provided the primary means for defining family firms (Chua et al., 1999; Sharma, 2004), and we perceived that firms with similar dynamics may not all consider themselves family firms. Therefore, by considering the fact that family firms differ in many dimensions from non-family firms (Chrisman et al., 2004, 2005), and, mostly, tend to pursue non-economic goals (Chrisman et al., 2012), both family involvement in ownership and in management may have positive and negative impacts on family business performance. This incorporation of this knowledge into an agency theory of the family firm is a very promising direction because the interlocking of systems within family firms (Gersick, Davis, Hampton, \& Lansberg, 1997) is complex in nature, and to understand this complexity, researchers may need to examine those relationships in a non-linear manner. These indications were observed in the studies conducted by Chrisman et al. (2004) and Sciascia and Mazzola (2008), and more recently by Mazzola et al. (2012) who found an inverted U-shaped relationship between the variables.

In summary, our study has some theoretical implications. Firstly, by focusing on agency theory, our research model captures a wide array of the dynamics within family firms and helps to explain the uniqueness of conflicts (that can arise because of the self-serving behaviour and asymmetric altruism) and their remedies. Secondly, in this we are in a better position to argue that the effects of agency costs on performance cannot be completely understood without taking into account the affinities among family members in the family firms, as well the communalities within the systems that govern the family firms. Thus, by integrating these two components in one model, we present a vast array of ideas about how family involvement and altruism may distinguish family and nonfamily firms in terms of performance. The model makes certain propositions. We believe, however, that empirical evaluation must be conducted to ascertain the validity of these propositions. A starting point for achieving this objective is, actually, to collect data, and examine whether and how the current frameworks can be applied within a different economic environment.

In conclusion, the family firm is an interesting topic of research and additional studies are needed on the conflicts of family firms and how they can be addressed. In this respect, we need to know what really makes some family owner-managed firms less willing to behave in a pro-organizational manner and behave more like one would expect the nonfamily firm to behave.

\section{References}

Anderson, R. C. and Reeb, D. M. (2003). Founding family ownership and firm performance: Evidence from the S\&P 500 Firms, Journal of Finance, 58(3), 1301-1327.

Anderson, R. C., Mansi, S. A. and Reeb, D. M. (2003). Founding family ownership and the agency cost of debt, Journal of Financial Economics, 68(2), 263-285.

Anderson, R. C. and Reeb, D. M. (2004): Board composition: Balancing family influence in S\&P 500 Firms, Administrative Science Quarterly, 49(2), 209-237.

Berger, A. N. and Udell, G. F. (2002). Small business credit availability and relationship lending: the importance of bank organizational structure, Economic Journal, 112(477), 43-53. 
Chrisman, J. J., Chua, J. H., Kellermanns, F. W., and Chang, E. (2007). Are family managers agents or stewards? An exploratory study in privately held family firms, Journal of Business Research, 60(10), 1030-1038.

Chrisman, J. J., Chua, J. H., and Litz, R. A. (2004). Comparing the agency costs of family and non-family firms: conceptual issues and exploratory evidence, Entrepreneurship Theory and Practice, 28(4), 335-354.

Chrisman, J. J., Chua, J. H., Pearson, A. W. and Barnett, T. (2012). Family involvement, family influence, and family-centered non-economic goals in small firms, Entrepreneurship Theory and Practice, 36(2), 267-293.

Chrisman, J. J., Chua, J. H. and Sharma, P. (2005). Trends and directions in the development of a strategic management theory of the family firm. Entrepreneurship Theory and Practice, 29(5), 555575.

Chrisman, J. J., Chua, J. H. and Steier, L. P. (2002). The influence of national culture and family involvement on entrepreneurial perceptions and performance at the State level. Entrepreneurship Theory and Practice, 26(4), 113-130.

Chrisman, J. J., Chua, J. H., and Steier, L. P. (2003). An introduction to theories of family business. Journal of Business Venturing, 18(4), 441448.

Chu, W. (2009). The influence of family ownership on SME performance: Evidence from firms in Taiwan. Small Business Economics, 33(3), 353-373.

Chua, J. H., Chrisman, J. J. and Bergiel, E. B. (2009). An agency theoretic analysis of the professionalized family firm. Entrepreneurship Theory and Practice, 33(2), 355-372.

Chua, J. H., Chrisman, J. J., Kellermanns, F. W. and $\mathrm{Wu}, \mathrm{Z}$. (2011). Family involvement and new venture debt financing. Journal of Business Venturing, 26(4), 472-478.

Chua, J. H., Chrisman, J. J. and Sharma, P. (1999). Defining the family Business by behavior. Entrepreneurship Theory and Practice, 23(4), 1939.

Corbetta, G. and Salvato, C. (2004). Self-serving or self-actualizing? Models of man and agency costs in different types of family firms: A commentary on Comparing the agency costs of family and nonfamily firms: Conceptual issues and exploratory evidence. Entrepreneurship Theory and Practice, 28(4), 355-362.

Cucculelli, M. and Micucci, G. (2008). Family succession and firm performance: Evidence from Italian family firms. Journal of Corporate Finance, 14(1), 17-31.

Davis, J., Schoorman, R., and Donaldson, L. (1997). Towards a stewardship theory of management. Academy of Management Review, $22(1), 20-47$.

DeAngelo, H. and DeAngelo, L. (2000). Controlling stockholders and the disciplinary role of corporate payout policy: A study of the Times Mirror Company. Journal of Financial Economics, 56(2), 153-207.

Dyer, W. G. (2006). Examining the family effect on firm performance. Small Business Review, 19(4), 253-273.

Faccio, M. (2010). Differences between politically connected and nonconnected firms: A cross-country Analysis. Financial Management, 39(3), 905-927.

Fama, E. F. and Jensen, M. C. (1983). Agency problems and residual claims. Journal of Law and Economics, 26(2), 327-349.

Fama, E. F. and Jensen, M. C. (1985). "Organizational forms and investment decisions," Journal of Financial Economics, 14(1), 101-119.

Gersick, K. E., Davis, J. A., Hampton, M. M., and Lansberg, I. S. (1997). Generation to generation: Lifecycles of family business. Harvard Business School Press, Boston, MA.

Gomez-Mejia, L. R., Nunez-Nickel, M. and Gutierrez, I. (2001). The role of family ties in agency contracts. Academy of Management Journal, $4(1), 81-95$.

Herrero, I. (2011). Agency costs, family ties, and firm efficiency. Journal of Management, 37(3), 887904.

James, H. S. (1999). What can the family contribute to business? Examining contractual relationship. Family Business Review, 12(2), 61-71.

Jensen, M. C. and Meckling, W. H. (1976). Theory of firm: Managerial behavior, agency costs and capital structure. Journal of Financial Economics, 3(4), 305-329.

Kellermanns, F. W. and Eddleston, K. (2004). Feuding families: when conflict does a family firm 
good. Entrepreneurship Theory and Practice, 28(3), 209-228.

Kidwell, R. E., Eddleston, K. A., Cater, J. J., and Kellermanns, F. W. (2012). How one bad family member can undermine a family firm: Preventing the Fredo effect. Business Horizon. In press.

Lansberg, I. S. (1983). Managing human resources in family firms: The problem of institutional overlap. Organizational Dynamics, 12(1), 39-46.

Maury, B. (2006). Family ownership and firm performance: empirical evidence from Western European corporations. Journal of Corporate Finance, 12(2), 321-341.

Mazzola, P., Sciascia, F. W., and Kellermanns, S. (2012). Non-linear effects of family sources of power on performance. Journal of Business Research, (in Press), 1-7.

McConaughy, D., Walker, M., Henderson, G. and Mishra, C. (1998). Founding family controlled firms. Review of Financial Economics, 7(1), 1-19.

Meyer, M., and Zucker, L. G. (1989). Permanently Failing Organizations. Sage: Newbury Park, CA.

Petersen, M.A. and Rajan, R., (1994). The benefits of lending relationships: evidence from small business data. Journal of Finance, 49(1), 337.

Randøy, T. and Goel, S. (2003). Ownership structure, founder leadership, and performance in Norwegian SMEs: implications for financing entrepreneurial opportunities. Journal of Business Venturing, 18(5), 619-637.

Romano, C. A., Tanewski, A. G. and Smyrnios, K. X. (2001). Capital structure decision making: A model for family business. Journal of Business Venturing, 16(3), 285-310.

Ross, S. (1973). The economic theory of agency: the principal's problem. American Economic Review, 63(2), 134-139.

Schulze, W. S., Lubatkin, M. H., Dino, R. N. and Buchholtz, A. K. (2001). Agency relationships in family firms: Theory and evidence. Organization Science, 12(2), 99-116.

Schulze, W. S., Lubatkin, M. H. and Dino, R. N. (2002). Altruism, agency, and the competitiveness of family firms. Managerial and Decision Economics, 23(4-5), 247-259.
Schulze, W. S., Lubatkin, M. H. and Dino, R. N. (2003a). Toward a theory of agency and altruism in family firms. Journal of Business Venturing, 18(4), 473-490.

Schulze, W. S., Lubatkin, M. H. and Dino, R. N. (2003b). Exploring the agency consequences of ownership dispersion among the directors of private family firms. Academy of Management Journal, 46(2), 179-194.

Sciascia, S. and Mazzola, P. (2008). Family involvement in ownership and management: Exploring nonlinear effects on performance. Family Business Review, 21(4), 331-345.

Sharma, P. (2004). An overview of the field of family business studies: Current status and directions for the future. Family Business Review, 17(1), 1-36.

Sharma, P., Chrisman, J. J. and Chua, J. H. (1997). Strategic management of the family business: Past research and future challenges. Family Business Review, 10(1), 1-35.

Smith, C. W. and Warney, J. B. (1979). On financial contracting: An analysis of bond covenant. Journal of Financial Economics, 7(2), 119-161.

Steijvers, T., and Voordeckers, W. (2009). Private family ownership and the agency costs of debt. Family Business Review, 22(4), 333-346.

Steijvers, T., Voordeckers, W. and Vanhoof, K. (2010). Collateral, relationship lending and family firms. Small Business Economics, 34(3), 243-259.

Stein, J. (1989). Efficient capital markets, inefficient firms: A model of myopic corporate behavior. Quarterly Journal of Economics, 103(4), 655-669.

Stiglitz, J. and Weiss, A. (1981). Credit rationing in markets with imperfect information. American Economic Review, 71(3), 393-410.

Storey, D. J. (1994). Understanding the Small Business Sector, Routledge: London.

Tagiuri, R. and Davis, J. A. (1992). On the goals of successful family companies. Family Business Review, 5(1), 43-62.

Tagiuri, R. and Davis, J. A. (1996). Bivalent attributes of the family firm. Family Business Review, 9(2), 199-208.

Villalonga, B. and Amit, R. (2006). How do family ownership control, and management affect firm value? Journal of Financial Economics, 80(2), 385-417. 
Wymenga, P., Spanikova, V., Barker, A., Konings, J. and Canton, E. (2012). EU SMEs in 2012: At the crossroads: Annual report on small and medium-sized enterprises in the EU, 2011/12. ECORYS: Rotherdan.
Zahra, S. A. (2003). International expansion of U.S. manufacturing family businesses: The effect of ownership and involvement. Journal of Business Venturing, 18(4), 495-512. 